\title{
The prevention of liver cancer and the epidemiology of cirrhosis
}

\begin{abstract}
The prevalence of liver cirrhosis in 133 Romanians as obtained from a published necropsy series was compared with the biopsy pattern seen among 138 Nigerians of the Igbo ethnic group. It was found that the Romanian peak age group of 50-59 years was 2 decades older than the Nigerian peak of 30-39 years. It is argued that, although one series was from necropsies and the other from biopsies, their distinct patterns are significant epidemiologically. Therefore, it is recommended that such comparative series, which ought to have an ethnic orientation wherever possible, should be undertaken internationally in order to map out the genetic and environmental factors inherent in liver cirrhosis which should be compared with the cancer of this organ. Indeed, the available evidence is that cirrhosis is the forerunner of malignancy. Accordingly, preventive measures are called for in the quest to lessen the burden of world-wide cancer of the liver. For example, the weighty words of the World Health Organization's book promote knowledge of the epidemiology of cirrhosis vis-à-vis liver cancer. Public health education is needed, therefore.
\end{abstract}

Keywords: liver, cirrhosis, cancer, epidemiology, prevention, romanians, nigerians
Volume 4 Issue 5 - 2016

\author{
Wilson Onuigbo \\ Department of Pathology, Medical Foundation and Clinic, \\ Nigeria
}

Correspondence: Wilson Onuigbo, Department of Pathology, Medical Foundation and Clinic, 8 Nsukka Lane, Enugu 40000I, Nigeria, Email Wilson.onuigbo@gmail.com

Received: June 24, 2015 | Published: April 19, 2016

\section{Introduction}

While receiving the Distinguished Service Award of the American Association for the Study of the Liver in 1983, Popper $^{1}$ considered the future of hepatology and affirmed that knowledge of diseases of the liver begins with epidemiology which is the basis for prevention.

One way of studying both genetic and environmental factors is to compare data derived from peoples living in different parts of the world. For example, Acalovschi et al. ${ }^{2}$ dealt with data which included the age incidence of cirrhotics recorded in nectropsies performed between 1973 and 1982 by the department of pathology of a big hospital in Romania. Therefore, I propose to compare their findings as to age prevalence with data collected personally in sub-Sahara Africa. The result should be of worldwide interest to hepatologists and others, especially in terms of the prevention of liver cancer.

\section{Materials and methods}

I studied the records of all the surgical specimens which I received and examined personally in a Regional Pathology Laboratory that serves mainly the Ibo or Igbo peoples ${ }^{3}$ of Eastern Nigeria, West Africa. I noted the cases of liver cirrhosis that were received between February 1970 and February 1999. Thereafter, I compared them with the published Romanian figures. Published data on liver cancer were also compared vis-à-vis the epidemiological analysis.

\section{Results}

Table 1 shows the incidence of cirrhosis by age groups among 133 Romanians and 138 Nigerian Igbos. It is clear that the peak age group among the Nigerians is 30-39 years, in contrast to Romanian's 50-59 years. Thus, one peak age is fully two decades later than the other.

\section{Discussion}

Recent opinion 4 is that "the significantly increased Hazard ratio of developing liver cancer among men with cirrhosis compared without cirrhosis in the United States may be contributing to the increasing incidence of liver cancer." If that be the case, there is need for comparative studies of both tropical and non-tropical populations. The present work was undertaken in this direction.

Table I Prevalence of cirrhosis in Romania and Nigeria

\begin{tabular}{|c|c|c|}
\hline Age (years) & Total Romanians & Total Nigerians \\
\hline $19-O c t$ & I & 3 \\
\hline $20-29$ & 5 & 25 \\
\hline $30-39$ & 3 & 36 \\
\hline $40-49$ & 18 & 33 \\
\hline $50-59$ & 46 & 23 \\
\hline $60-69$ & 37 & 4 \\
\hline $70-79$ & 21 & 4 \\
\hline $80-89$ & 2 & 0 \\
\hline Grand Total & 133 & 138 \\
\hline
\end{tabular}

According to Sheila Sherlock, ${ }^{5}$ the general role of cirrhosis is clearly important when considering the patterns of hepatocyte injury in man. For instance, on tabulating national versus urban incidences of liver cirrhosis in 7 countries, German workers ${ }^{6}$ concluded that this lesion preponderates in major towns. Unfortunately, this Nigerian series does not have the residential details necessary for such a comparison.

Tiwary and his Indian co-workers ${ }^{7}$ doubted the utility of histobioptic studies in cirrhosis patients on account of the practical problems encountered by them. Fortunately, Al Saihi and associates ${ }^{8}$ have introduced inexpensive, non invasive, optical technique which may have significant impact in screening, diagnosis and also prognosis of HCC in large segment of people in the populous Asian countries." No doubt, this should be the case elsewhere in the world. ${ }^{9}$ Now, there is an upsurge of evidence based pathology. ${ }^{10}$ Therefore, the present paper asks a question which can be answered with relevant databases worldwide, namely, is the prevention of liver cancer explicable on the comparative epidemiology of cirrhosis? 


\section{Conclusion}

It is generally accepted that cirrhosis due to any cause may predispose to liver cancer, ${ }^{11}$ and that this condition is more frequent in geographic areas of high incidence of liver cancer. ${ }^{12}$ Indeed, in the World Health Organization's tome on "Cancer in Africa. Epidemiology and prevention", ${ }^{13}$ the lesson is clear: "At the individual level, consumers can be educated to avoid obviously mouldy grains, and to consume a more varied diet, with less reliance on staple crops (especially maize and peanuts) that are heavily contaminated with aflatoxin ." "Chemoprevention," it continued, "is a different approach to prevention of aflatoxin toxicity ..." Thus, I agree with Akinkugbe ${ }^{13}$ that "In the setting of a developing country one must give due prominence to public health the central pivot around which most health planning in these localities should rotate."

\section{Conflicts of Interest}

The authors declare no conflict of interest.

\section{Acknowledgments}

None.

\section{Funding}

None.

\section{References}

1. Popper H. The future of hepatology. Hepatology. 1984;4(1):152-155.
2. Acalovschi M, Dumitrascu D, Ban A, Petrescu A. A necroptic study of the prevalence of cholelithiasis in liver cirrhosis. Med Interne. 1986;24(1):23-27.

3. Basden GT. Niger Ibos. Frank Cass, London, England. 1966.

4. Hutt MSR, Gibson JB. Cirrhosis and other liver disorders. In: Spencer $\mathrm{H}$ (Ed.), Tropical Pathology. Springer-Verlag, New York, USA. 1973;668.

5. Sherlock S. Patterns of hepatocyte injury in man. Lancet. 1982;31(8275):782-786.

6. Jorke D, Reinhardt M (1977) Epidemiology of chronic liver disease. Acta Hepato-Geastroenterol. 1977;24(4):220-225.

7. Tiwary A, Sahaya R, Verma. The utility of histiobioptc studies in cirrhosis of the liver. Clinician. 1981;45:463-466.

8. Skinhoj P, Hart Hansen JP, Nielsen NH, et al. Occurrence of cirrhosis and primary liver cancer in an Eskino population hyperendemically infected with hepatitis B virus. Am J Epidemol. 1978;108(2):121-125.

9. Booth A. Mapping the evidence base of pathology. J Pathol. 1999;188:344-350.

10. Editorial: More on the aflatoxin-hepatoma story. $\mathrm{Br}$ Med $\mathrm{J}$. 1975;2(5972):647-648.

11. Elsner B, Janregui EM. Autopsy study of primary liver carcinoma in Buenos Aires, Argentina. Acta Hepato-Gastroenterol. 1974;21(1):2634.

12. Parkin DM, Ferlay J, Hamdi-Chérif M, et al. Cancer in Africa: Epidemiology and prevention. IARC Press, Lyon, France, 2003;p. 310.

13. Akinkugbe OO. Role of teaching hospitals in a developing country. $\mathrm{Br}$ Med J. 1973;1(5851):474-476. 